\title{
Morphometric Analysis of a Tropical Medium River System: A Case from Bharathapuzha River Southern India
}

\author{
P. P. Nikhil Raj, P. A. Azeez \\ Sálim Ali Centre for Ornithology and Natural History (SACON), Coimbatore, India. \\ Email: ppnraj@gmail.com, azeezpa@gmail.com
}

Received June $3^{\text {rd }}$, 2012; revised July $15^{\text {th }}$, 2012; accepted August $1^{\text {st }}, 2012$

\begin{abstract}
Baseline morphometric information at a sub basin level is essential to develop appropriate strategy for sustainable, socially acceptable, ecologically benign and economically viable development of a river basin. The present study was carried out in one of the less studied Bharathapuzha river basin (BRB), the second longest river in the state of Kerala, India. The annual discharge of the river is $3.94 \mathrm{~km}^{3}$. Nevertheless the basin, which receives about $1828 \mathrm{~mm}$ of annual rainfall, in recent years has been facing dearth of water. We used GIS and RS tools to study the morphometric characteristics of the basin. The seventh order main river is formed by several lower order streams forming a dentritic flow pattern. Basin geology, slope and rainfall pattern in the basin determine the morphometric characteristics of the basin. The linear aspects of the basin including stream length ratio and bifurcation ratio indicate the role of relief in the basin while the areal ratios indicate the elongate nature of the basin.
\end{abstract}

Keywords: Bharathapuzha River Basin (BRB); Morphometry; GIS; RS

\section{Introduction}

Morphometric analysis provides quantitative expression of drainage basins, and is regarded as one important tool in hydric analysis [1] providing simple and accurate measures to document the drainage systems [2]. Morphometric analysis brings out the basic characters on the geometrical and mechanical aspects of the river basin which in turn would be helpful in understanding the hydrology, sediment characteristics and landscape evolution of basins. River basins are considered as an open system and the basic steps involved in morphometric analysis are defining, measuring and analyzing the quantitative indices related to flow plane geometry and profile, and bed form of river basins. The morphometric analysis examines linear and areal aspects of the drainage networks [3].

Due to several anthropogenic pressures and global climate variations most of the world's fresh water flow regimes are under severe threat. Therefore documenting basin characteristics using morphometric techniques, well-known since early nineteenth century, are very essential. The studies by Horton [4], Starhler [5,6], Schumm [7] are considered land marks in the field. Studies conducted by Dade [8], Singh et al. [9], Sreedevi et al. [10] Mesa [2], Rao et al. [11], Sarkar and Gundekar [12], Rudraiah et al. [13], Angillieri [1], Thomas et al. [14] are some of the later morphometric studies. The recent studies make use of the high potentials of Geographic Information System (GIS) and Remote Sensing (RS) as the most popular and effective tools to investigate the river morphometry and basin characters.

The state of Kerala, placed at the southwest corner of India $\left(8.5^{\circ}-11^{\circ} \mathrm{N}\right.$ and $\left.76^{\circ}-77^{\circ} \mathrm{E}\right)$ is bestowed with 44 rivers. The net-work of their tributaries and distributaries cover almost $74 \%$ of the total surface area of the state. It is supposed that the state is aplenty in water availability. However, a recent study found that Kerala's per capita water availability lies far below the more arid states of India such as Rajasthan and Maharashtra [15]. Unsustainable exploitation of natural resources and untenable encroachment of the river course and basin areas are the probable grounds for dying rivers of the state. Extensive mining of sand and clay have interfered with the flow regime of many of the tributaries [16]. Though the state is rich in number of rivers flowing through it studies related to Morphometry are rare. In this context, the present study examines the morphometric characteristics of Bharathapuzha River, using GIS and RS tools.

\section{Study Area}

The Bharathapuzha River $\left(10^{\circ} 25^{\prime}\right.$ to $11^{\circ} 15^{\prime}$ north and $75^{\circ} 50^{\prime}$ to $76^{\circ} 55^{\prime}$ east) is the second longest (209 km) and largest (annual discharge $3.94 \mathrm{~km}^{3}$ ) among the west flowing perennial rivers (41 in number) in the state of 
Kerala in India (Figure 1). The river basin covers $1 / 9$ of the total geographical area of the state. The flow regime of the river covers highlands ( $>76 \mathrm{~m}$ above MSL), midlands ( 8 - $76 \mathrm{~m}$ above MSL) and the low lands $(<8 \mathrm{~m}$ above MSL). The river has a well-developed flood plain and fluvial terrace of recent origin. The annual discharge of the river at its confluence is $3.94 \mathrm{~km}^{3}$ [17]. The river is the life line water resource for more than 4.5 million people residing in five administrative districts, namely Malappuram, Trissur and Palakkad districts of Kerala, and Coimbatore and Thiruppur districts of Tamil Nadu. There are eleven dams and irrigation projects in the river basin catering 493,064 ha cultivations [18,19]. In recent years, the basin is facing severe dearth of water and drought like situations, perhaps for the increasing anthropogenic pressures and development works that grossly neglect the hydrologic flow regime of the basin. Unsustainable exploitation of water, in stream sand mining and clay mining for brick kilns are among the striking threats to flow of the river.

The location of the BRB in the Palakkad gap, the most prominent physiographic and morphologic feature, the 30 $\mathrm{km}$ wide opening in the whole of $1300 \mathrm{~km}$ long Western
Ghats, provides a climatic realm for the basin from the rest of south India [20]. The average annual rainfall in the BRB is $1828 \mathrm{~mm}$ with a standard deviation of 456.6 $\mathrm{mm}$. Among the months, while July experiences highest rainfall $(525 \mathrm{~mm})$, almost $29 \%$ of the total annual rainfall in the basin, January receives the lowest $(3 \mathrm{~mm})$. Among the two chief rainy seasons, rainfall is highest during south west monsoon season $(1318 \mathrm{~mm}$ with a standard deviation of $391 \mathrm{~mm}$ ) followed by north east The mean annual temperature of the basin was $22.86^{\circ} \mathrm{C}$ with a standard deviation of $0.5^{\circ} \mathrm{C}$. April is the hottest (mean temperature $26.78^{\circ} \mathrm{C}$ ) month in the basin.

Geologists consider the basin as a successor to a westerly flowing palaeo-river during the post Mio-Pliocene time [21-23]. Vaidyanadhan [23] as well as certain LANDSAT imageries have also identified certain palaeoriver channels tending towards the east flowing Amravati river basin through the present day river course. BRB has a wide variety of geological formations including archean crystallines, laterites and coastal sand and alluvium (Figure 2). The archean crystallines is seen in almost entire basin except the river mouth. The main river channel is characterized by chrnockites, garnet sillimanite

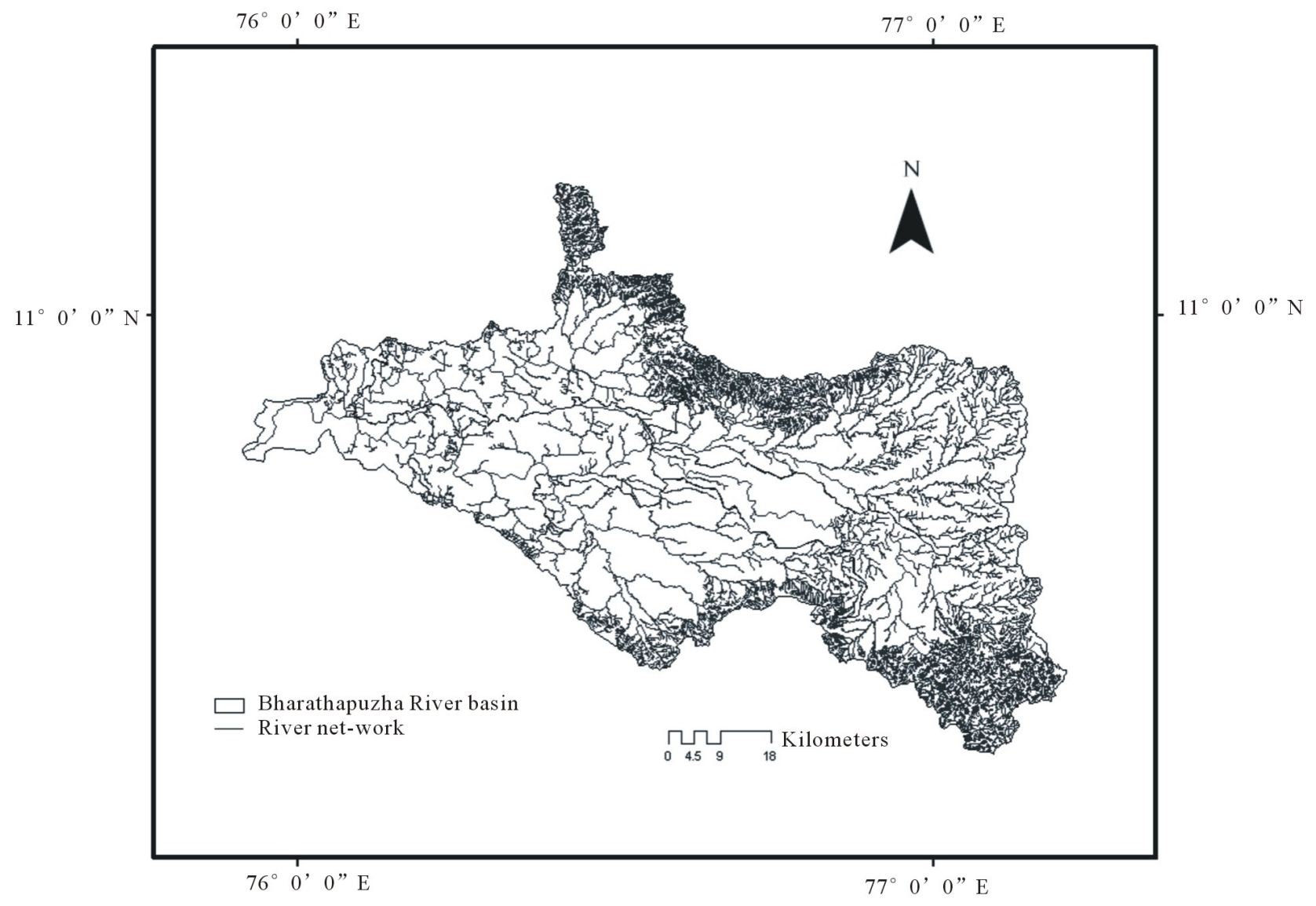

Figure 1. Location and drainage pattern in BRB, South India. 


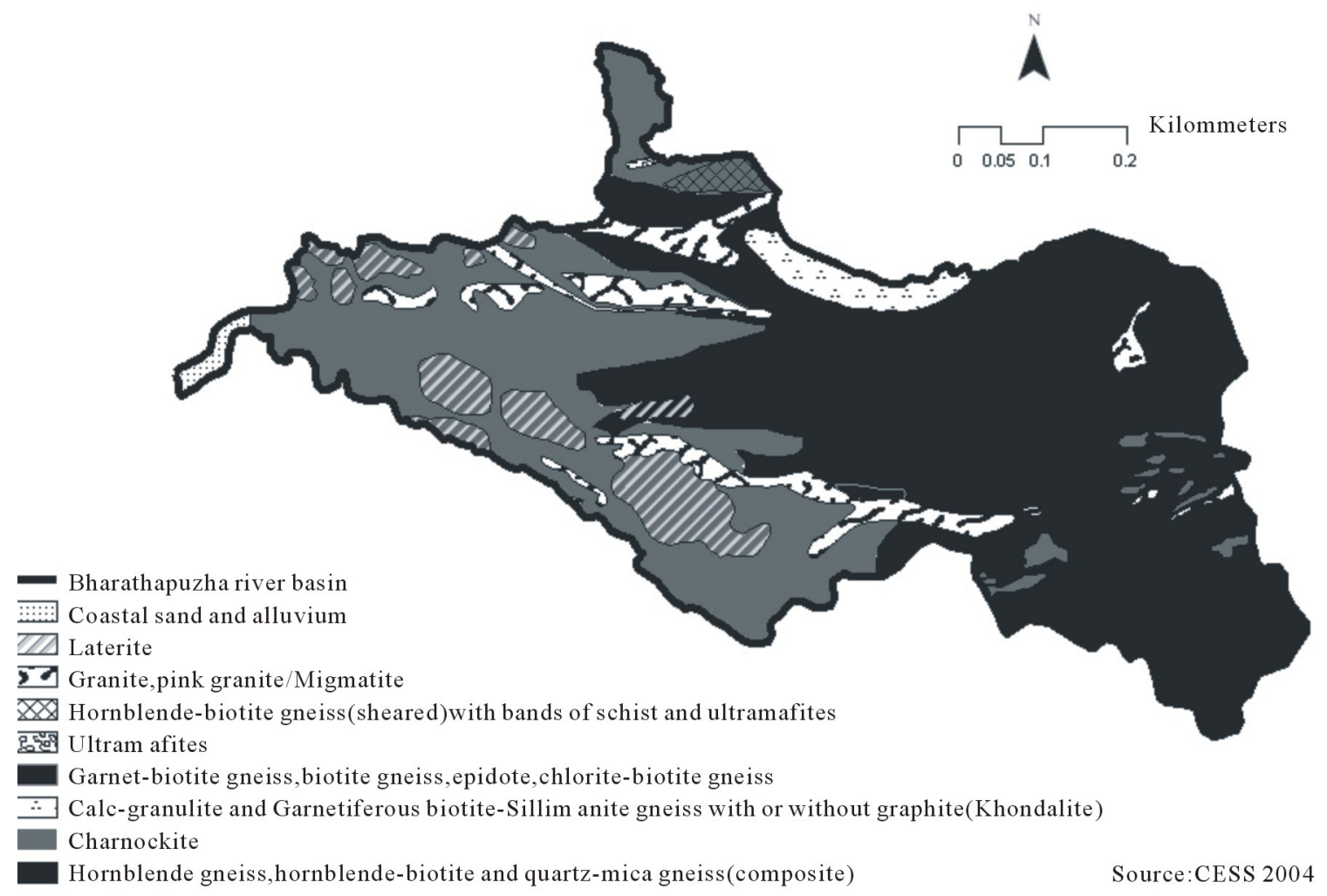

Figure 2. Geology of BRB.

gneisses (Khondalites), calc granulite and associated crystalline limestones, hornblende-biotiteg-neisses, granites and quatzo-fledspathic gneisses. In many places in the basin the crystallines are seen capped over by laterites. The basic metamorphic bodies and acid intrusives are represented by pyroimite, amphibolite, dolerite, pegmatite, and quartz vein. Coastal sands and alluvium forms recent to sub recent depositions in sediments at river mouth in the form of semi consolidated and variegated tertiary sandstones and clay stones. The eastern boundary of the basin is characterized by deposition of Kankar-a product of chemical weathering of country rocks in dry and semi-arid climate [24].

\section{Methodology}

Survey of India (SOI) topographic map series (58 $\mathrm{A} / 4$, $\mathrm{A} / 8, \mathrm{~A} / 12, \mathrm{~A} / 16, \mathrm{E} / 4, \mathrm{~B} / 1, \mathrm{~B} / 5, \mathrm{~B} / 9, \mathrm{~B} / 13, \mathrm{~B} / 2, \mathrm{~B} / 6, \mathrm{~B} / 10$, $\mathrm{B} / 14, \mathrm{~F} / 2, \mathrm{~B} / 11, \mathrm{~B} / 15, \mathrm{~F} / 3 ; 49 \mathrm{~N} / 13, \mathrm{~N} / 14$ ) of scale $1: 50,000$ were used as the base maps for delineation of $\mathrm{BRB}$ and its sub basins. We also used land sat imageries available at www.landcover.org for the morphometric analysis. The slope and relief of the basin were examined using digital elevation model data (DEM) available at www.asterdem.com. The stream order, stream length, mean stream length, stream length ratio, bifurcation ratios, mean bifurcation ratio, relief ratio, drainage density, stream frequency, drainage texture, form factor, circulatory ratio and elongation ratio were estimated. We used Arc GIS 9.3 and ERDAS IMAGINE 8.5 for the entire study.

\section{Results and Discussions}

The basin extends between Western Ghats and the Palakkad gap on its east, narrowing down to the Arabian seacoast at the west. The four major tributaries of the river are namely Kalpathypuzha, Gayathripuzha, Thootha, and Chitturpuzha basins, all originating from the Western Ghats. The drainage pattern of the river Bharathapuzha is dendritic in nature, a pattern very common in areas with horizontal sedimentary rocks [10]. The total drainage area of the Bharathapuzha basin is $6186 \mathrm{~km}^{2}$ of which $4400 \mathrm{~km}^{2}$ falls in the state of Kerala and the rest in Tamil Nadu state of India. The areas under each sub basin are given in Table 1. Kalpathy is the largest basin while Thootha forms the smallest one among the four sub-basins. The perimeter, the total length of the drainage basin boundary of the whole BRB, is $1215.4 \mathrm{~km}$. The perimeter ranges in the order Chittur $>$ Tootha $>$ Kalpathy $>$ Gayathri among the sub basins (Table 2). The basin length, the maximum length measured parallel to the main drainage line [4], was estimated individually for each sub basins. The highest basin length was found in 
Table 1. Stream order in the Bharathapuzha river basin.

\begin{tabular}{|c|c|c|c|c|c|c|c|c|c|}
\hline \multirow{2}{*}{ Basin } & \multirow{2}{*}{$\begin{array}{c}\text { Basin area } \\
\left(\mathbf{k m}^{2}\right)\end{array}$} & \multirow{2}{*}{ Stream order } & \multicolumn{7}{|c|}{ Stream order } \\
\hline & & & 1 & 2 & 3 & 4 & 5 & 6 & 7 \\
\hline Bharathapuzha river & 6102.34 & 7 & 5628 & 1321 & 324 & 70 & 19 & 5 & 1 \\
\hline Chittur & 1314.71 & 7 & 2162 & 494 & 115 & 22 & 6 & 2 & 1 \\
\hline Kalpathy & 1390.16 & 6 & 1198 & 291 & 73 & 18 & 5 & 1 & \\
\hline Gayathri & 1084.69 & 6 & 633 & 165 & 44 & 8 & 3 & 1 & \\
\hline Thootha & 1015.3 & 6 & 1325 & 296 & 72 & 17 & 5 & 1 & \\
\hline
\end{tabular}

Table 2. Relief ratio and Elongation ratio of BRB.

\begin{tabular}{ccccc}
\hline Basin name & Perimeter $\mathbf{( k m )}$ & Basin length & Relief ratio & Elongation ratio \\
\hline Bharathapuzha river & 1215.4 & 133 & 17.90 & 0.66 \\
Chittur & 273.5 & 78 & 30.00 & 0.52 \\
Kalpathy & 211.1 & 63 & 31.52 & 0.67 \\
Gayathri & 194.6 & 56 & 19.89 & 0.66 \\
Thootha & 251.3 & 58 & 37.79 & 0.62 \\
\hline
\end{tabular}

the case of Chittur basin followed by the Kalpathy, Thootha, and Gayathri basins (Table 3). Determining the stream order is one of the early steps in study of drainage basin. The stream ordering was done following Strahler [6]. The main river is of $7^{\text {th }}$ order and among the four basins while river Chittur fall in $7^{\text {th }}$ order and all others fall in $6^{\text {th }}$ order (Table 1). The number of streams gradually decreases as the stream order increases following the Horton's first law (Figure 3). Physiography and structural condition of the basin are the important factors influencing the number and order of the streams.

From the topographic map the lengths of all the streams in the basin falling under different stream orders were measured (Table 3) and as is expected the total stream length of each segment increases with the increasing stream order (Figure 4, see Table 4 for mean stream lengths of each tributaries). This indicates the decrease in the slope in the basin's terrain, tending towards the coastal belt from the higher altitude Western Ghats. It is also observed that the stream length characteristic of the basin follows Horton's second law $[4,25]$. Mean stream length (the ratio of the total number of stream segment of a particular order to the total stream length of the same order) is believed to be a distinctive property of a river channel relating the drainage network components and its associated basin surfaces [6]. The stream length shows an abrupt increase in $4^{\text {th }}$ and above order for the main river as well as all the tributaries, indicating the pressure exertion from the structural elements especially slope and high amount of rainfall [14]. Study conducted by Thomas et al. [14] in Muthirapuzha river basin located south of BRB in the Western Ghats also show similar pattern in mean stream length ratio. This characteristic of BRB indicates the geologic evolution of the basin is more or less according to the geologic erosion laws with homogenous characteristics of weathering [3]. The stream length ratio of the drainage system was calculated as the ratio between total stream lengths of the order to total stream length of its next order [4]. The stream length ratio of the main stream of the river ranges from 0.38 to 1.15 . The stream length ratios of all the four tributaries were also found varying considerably (0.30 to 1.75, Table 3). The stream length ratio of BRB and its sub basins were found to be varying anomalously. This variation could be easily explained as the down stream extension of the higher order stream or upward extension of tributaries or inception [14]. The change in the mean stream length ratio is an indicator of the changes in the slope and topography, which in turn determine the age of the basin [13]. The stream length ratio is also reported to have a vital role in surface flow discharge and sedimentation stage of the basin [10].

The Bifurcation ratio is a dimensional parameter, derived as the ratio between the numbers of streams of any given order to the number in the next lower order [26]. This is considered to be an important parameter that articulates the degree of ramification of the drainage network [2] and an indicator of the geological condition of the basin [5]. At the whole basin and sub basin level, the bifurcation ratio of the study area varies more or less gradually ranging from 2 to 5.50 (Table 5), ascribed to mountainous or highly dissected basin areas [4]. However, 


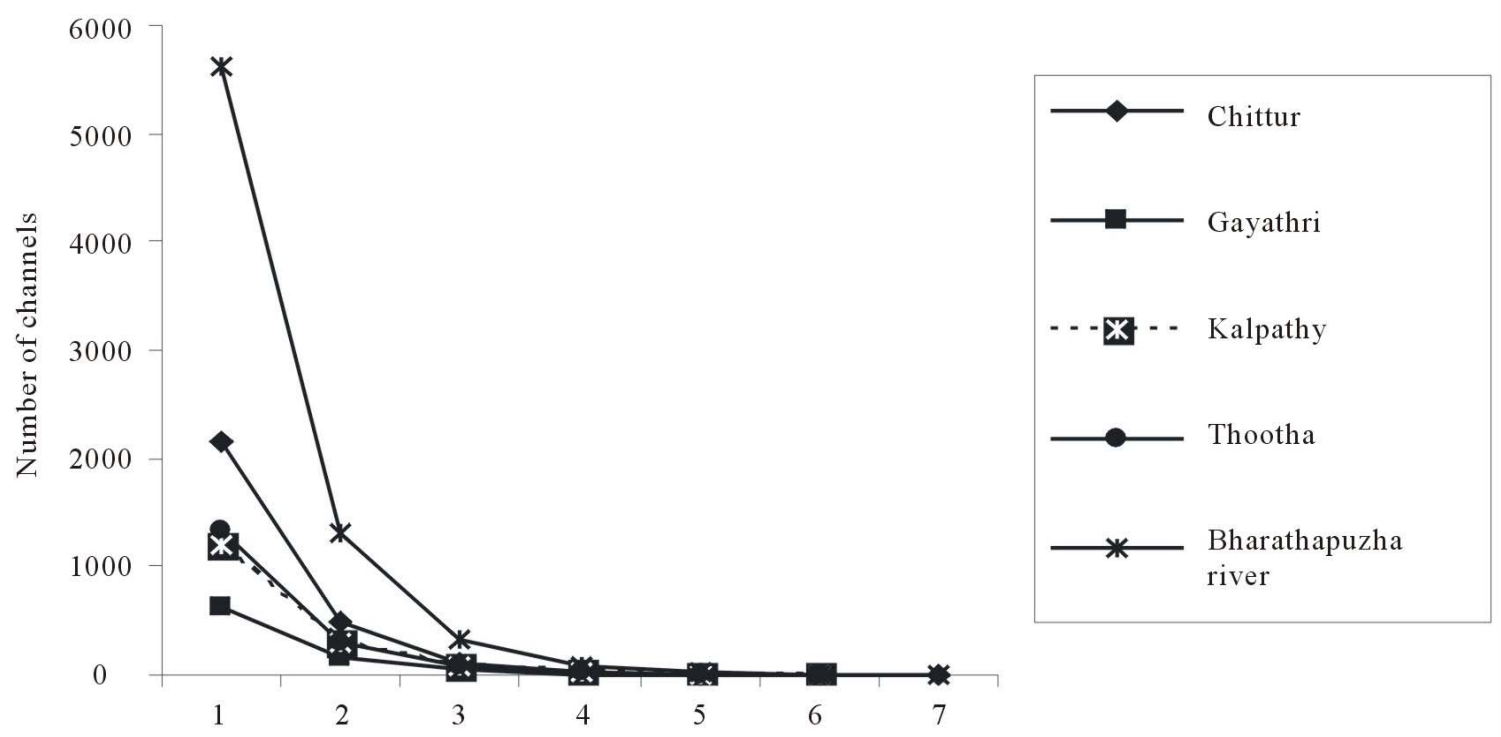

Figure 3. Relationship between stream order and number of streams in BRB.

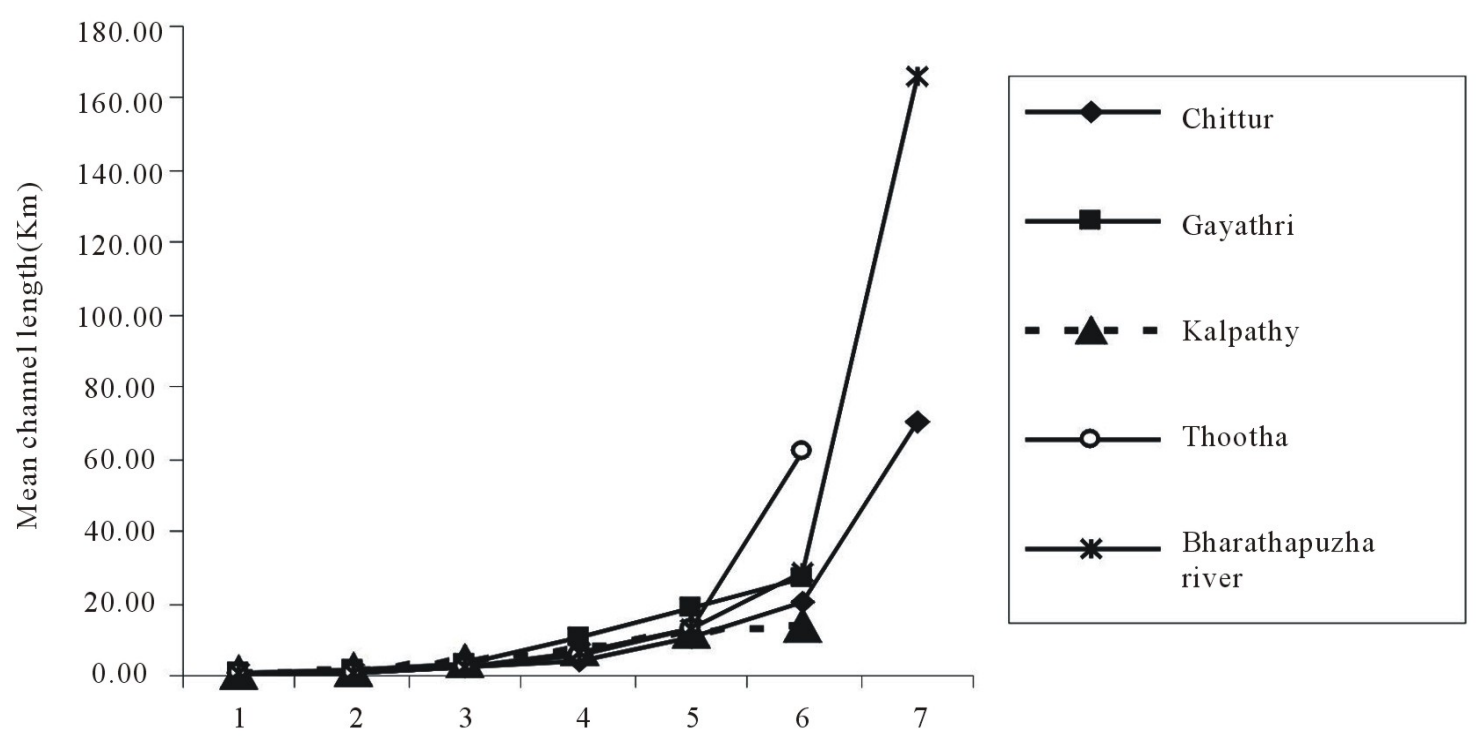

Figure 4. Relationship between mean channel length and stream order in BRB.

Table 3. Stream length and stream length ratio of BRB.

\begin{tabular}{|c|c|c|c|c|c|c|c|c|c|c|c|c|c|c|}
\hline \multirow{2}{*}{ Basin name } & \multicolumn{7}{|c|}{ Order wise stream length (km) } & \multirow[t]{2}{*}{$\begin{array}{l}\text { Total } \\
(\mathbf{k m})\end{array}$} & \multicolumn{6}{|c|}{ Stream length ratio } \\
\hline & 1 & 2 & 3 & 4 & 5 & 6 & 7 & & $2 / 1$ & $3 / 2$ & $4 / 3$ & $5 / 4$ & $6 / 5$ & $7 / 6$ \\
\hline $\begin{array}{l}\text { Bharathapuzha } \\
\text { river }\end{array}$ & 3884.80 & 1469.65 & 906.93 & 433.50 & 248.71 & 144.05 & 166.17 & 7253.82 & 0.38 & 0.62 & 0.48 & 0.57 & 0.58 & 1.15 \\
\hline Chittur & 1329.24 & 428.95 & 237.07 & 84.17 & 66.04 & 40.24 & 70.30 & 2256.01 & 0.32 & 0.55 & 0.36 & 0.78 & 0.61 & 1.75 \\
\hline Kalpathy & 929.04 & 392.59 & 279.13 & 134.20 & 61.03 & 14.16 & & 1810.13 & 0.42 & 0.71 & 0.48 & 0.45 & 0.23 & \\
\hline Gayathri & 522.93 & 234.51 & 137.24 & 87.29 & 55.53 & 27.15 & & 1064.65 & 0.45 & 0.59 & 0.64 & 0.64 & 0.49 & \\
\hline Thootha & 803.85 & 241.82 & 183.50 & 91.20 & 66.11 & 62.50 & & 1448.97 & 0.30 & 0.76 & 0.50 & 0.72 & 0.95 & \\
\hline
\end{tabular}


Table 4. Mean Stream length of BRB.

\begin{tabular}{ccccccccc}
\hline \multirow{2}{*}{ Basin name } & \multicolumn{9}{c}{ Mean stream length (km) } \\
\cline { 2 - 8 } & $\mathbf{1}$ & $\mathbf{2}$ & $\mathbf{3}$ & $\mathbf{4}$ & $\mathbf{5}$ & $\mathbf{6}$ & $\mathbf{7}$ \\
\hline Bharathapuzha river & 0.69 & 1.11 & 2.80 & 6.19 & 13.09 & 28.81 & 166.17 \\
Chittur & 0.61 & 0.87 & 2.06 & 3.83 & 11.01 & 20.12 & 70.30 \\
Kalpathy & 0.78 & 1.35 & 3.82 & 7.46 & 12.21 & 14.16 & 27.15 \\
Gayathri & 0.83 & 1.42 & 3.12 & 10.91 & 18.51 & 13.22 & 62.50 \\
Thootha & 0.61 & 0.82 & 2.55 & 5.36 & & \\
\hline
\end{tabular}

Table 5. Bifurcation ratio and mean bifurcation ratio of BRB.

\begin{tabular}{ccccccccc}
\hline \multirow{2}{*}{ Basin name } & \multicolumn{9}{c}{ Bifurcation ratio (RL) } & \multicolumn{2}{c}{ Mean bifurcation } \\
\cline { 2 - 8 } & $\mathbf{1 / 2}$ & $\mathbf{2 / 3}$ & $\mathbf{3 / 4}$ & $\mathbf{4 / 5}$ & $\mathbf{5 / 6}$ & $\mathbf{6 / 7}$ & 4.24 \\
\hline Bharathapuzha river & 4.26 & 4.08 & 4.63 & 3.68 & 3.80 & 5.00 & 3.76 & 4.15 \\
Chittur & 4.38 & 4.30 & 5.23 & 3.67 & 3.00 & 2.00 & 3.75 \\
Kalpathy & 4.12 & 3.99 & 4.06 & 3.60 & 5.00 & & 4.24 \\
Gayathri & 3.84 & 3.75 & 5.50 & 2.67 & 3.00 & & \\
Thootha & 4.48 & 4.11 & 4.24 & 3.40 & 5.00 & & & \\
\hline
\end{tabular}

as suggested by Chow [25], these values may indicate the area is not influenced powerfully by geological structures. The closeness in mean bifurcation values among the basins on the other hand shows the similarity in the geological set ups [14]. Present analysis of bifurcation ratio in BRB is not following the hypothesis of Giusti and Schneider [27]. According to them the bifurcation ratio is inversely proportional to the stream order. This is perhaps due to the influence of the relief. Relief is the altitudinal difference between the maximum and minimum elevation points in the basin. The relief ratio is an adimensional ratio derived from the relief of the basin, calculated as the ratio between basin length to the total relief of the basin [26]. It is an important factor indicating the denudational characteristics of the basin. Normally the relief ratio is inversely proportional to the drainage area of the basin [28]. However, in case of BRB this relationship could not found (Table 2).

By definition drainage density of a basin is the total length of the streams of all orders per drainage area [4]. Drainage density is believed to be highly influenced by environmental factors such as climate, infiltration capacity of the area, rock type, relief, vegetation cover, surface roughness, and runoff intensity. The drainage density of the BRB was 6.06. Among the four sub basins of the river, highest drainage density was found in the case of Chittur and lowest in the case of Gayathri (Table 6). The higher drainage density of the BRB suggests the sparse vegetation and mountainous relief, while in the sub basin level it indicate highly permeable sub soil, with moderate vegetative cover as suggested by Rudraiah et al. [13] for Kagna river basin, Karnataka, India.

Stream frequency of a basin is defined as the ratio between total number of segments cumulated for all order within a basin and the basin area [4]. Regarding the stream frequencies of the Bharathapuzha river and its sub basins, Chittur sub basin have highest number (Table 6) followed by Thootha sub basin. The stream frequency appears to be correlated well with relief factor and slope of the area. The provenance of Chittur and Thootha sub basins are in the high altitudes in the Anamalai reserve forest and Silent valley National park respectively.

Drainage texture is the total number of stream segments of all the orders to the perimeter of that basin [4]. The drainage texture of a basin have direct relation with climate, rainfall, vegetation cover, rock and soil type, infiltration capacity, and relief and stage of development [29]. It is considered to be one of the prime features of the basin geomorphology. Weak rocks devoid of vegetative cover produce fine texture, while rocks which are hard and with vegetative cover produce coarse texture. Sparse vegetation in arid climate causes finer texture than in humid regions. Smith [29] have classified five different drainage textures related to various drainage densities as very coarse (below 2), coarse (2 - 4), moderate ( 4 - 6), fine ( 6 - 8 ) and very fine (8 and above). The highest value for drainage texture was found in the case of Chittur basin indicating "very fine" nature of the drainage 
Table 6. Drainage density, texture ratio, form factor and circulatory ratio of BRB.

\begin{tabular}{cccccccc}
\hline Basin name & $\begin{array}{c}\text { Drainage } \\
\text { density }\end{array}$ & $\begin{array}{c}\text { No. of } \\
\text { streams }\end{array}$ & $\begin{array}{c}\text { Stream } \\
\text { frequency }\end{array}$ & Texture ratio & $\begin{array}{c}\text { Form } \\
\text { factor }\end{array}$ & $\begin{array}{c}\text { Circulatory } \\
\text { ratio }\end{array}$ \\
\hline Bharathapuzha river & 6.06 & 7368.00 & 1.21 & 6.06 & 0.34 & 0.05 \\
Chittur & 1.72 & 2802 & 2.13 & 10.24 & 0.22 & 0.22 \\
Kalpathy & 1.30 & 1586 & 1.14 & 7.51 & 0.35 & 0.39 \\
Gayathri & 0.98 & 854 & 0.78 & 4.39 & 0.35 & 0.36 \\
Thootha & 1.43 & 1716 & 1.69 & 6.83 & 0.30 & 0.20 \\
\hline
\end{tabular}

system; in Gayathri basin the texture was found to be "moderate" (Table 6).

Form factor, the ratio of the area of the basin to the square of basin length [4], for the basin and all its sub basin (Table 6), except in the case of the Chittur sub basin, were more or less very close. The Chittur sub basin on the other hand is a narrow basin with comparatively less number of drainage net works. Circulatory ratio, that can be expressed as the ratio of the basin area to the area of a circle with same perimeter as the basin [30], is more influenced by length, frequency, and stream gradients of various orders than slope condition and drainage pattern of the basin. According to Sreedevi et al. [10] it is a significant ratio indicating the dentritic stage of the basin. In all the sub basins of BRB the circularity ratio were found ranging from $0.20-0.39$ indicating the basin to be more elongated than circular (Table 6) indicate the youth stage of the river network. And the low value of circulatory ratio of the basins indicates their elongated shape and that is clearly due to its location in the Palakkad Gap in the Western Ghats. The elongated shape of the BRB and its sub basins can be visualized well by measuring the elongation ratio. It is the ratio between the diameter of the circle of the same area as the drainage basin and the maximum length of the basin [26]. The elongation ratio of the basin as well as sub basin level of BRB is displayed in the Table 2. Since water lag of a basin can be determined from its elongation ratio, it is a necessarily important feature to be found prior to any programs of harnessing a river flow for any developmental activities.

\section{Conclusion}

BRB is one of the highly exploited river basins in the state of Kerala, India, however the scientific documentation on the river basin is very scarce. The present study generates baseline information on the morphometric characteristics of the river basin as well as its sub basins. BRB is a seventh order river basin with four sub basins. The drainage pattern of the BRB is dentritic. The mean stream length of the river was found ranging between 0.69 to $166.17 \mathrm{~km}$ among different stream orders. The drainage texture of the basin falls under "fine" category.
The elongation and circulatory ratios shows the elongative nature of the basin. The peculiar location in the Palakkad Gap of the Western Ghats with unique geological characteristics greatly influences the morphometry of the river basin. Other aspects such as slope, relief, and environmental factors such as rainfall also had considerably contributed to the basin morphometry. Documentation of the morphometric characters can be well utilized for conservation and sustainable management of the BRB and also is essentially necessary to develop appropriate strategy for socially acceptable, ecologically benign and economically viable development of the river basin.

\section{REFERENCES}

[1] M. Y. E. Angillieri, "Morphometric Analysis of Colanguil River Basin and Flash Flood Hazard, San Juan, Argentina,” Environmental Geology, Vol. 55, No. 1, 2008, pp. 107-111. doi:10.1007/s00254-007-0969-2

[2] L. M. Mesa, "Morphometric Analysis of a Subtropical Andean Basin (Tucumán, Argentina)," Environmental Earth Sciences, Vol. 50, No. 8, 2006, pp. 1235-1242. doi:10.1007/s00254-006-0297-y

[3] S. K. Nag and S. Chakraborty, "Influences of Rock Types and Structures in the Development of Drainage Network in Hard Rock Area," Journal of Indian Society Remote Sensing, Vol. 31, No. 1, 2003, pp. 25-35.

[4] R. E. Horton, "Erosional Development of Streams and Their Drainage Basins; Hydrophysical Approach to Quantitative Morphology," Geological Society of American Bulletin, Vol. 56, No. 3, 1945, pp. 275-370. doi:10.1130/0016-7606(1945)56[275:EDOSAT]2.0.CO;2

[5] A. N. Strahler, "Quantitative Analysis of Watershed Geomorphology,” Transactions-American Geophysical Union, Vol. 8, No. 6, 1957, pp. 913-920.

[6] A. N. Strahler, "Quantitative Geomorphology of Drainage Basin and Channel Networks,” In: V. T. Chow, Ed., Handbook of Applied Hydrology, McGraw Hill Book Company, New York, 1964.

[7] S. A. Schumm, "Sinuosity of Alluvial Rivers on the Great Plains,” Geological Society of America Bulletin, Vol. 74, No. 9, 1963, pp. 1089-1100. doi:10.1130/0016-7606(1963)74[1089:SOAROT]2.0.CO;2

[8] W. B. Dade, "Multiple Scales in River Basin Morphology,” American Journal of Science, Vol. 301, No. 1, 2001, 
pp. 60-73. doi:10.2475/ajs.301.1.60

[9] R. K. Singh, S. K. Saha and S. Kumar, "Soil Conservation Prioritization of Watershed Based on Erosional Soil Loss and Morphometric Analysis Using Satellite Remote Sensing \& GIS-A Case Study,” Map India, 2005. http://www.gisdevelopment.net/application/nrm/water/wa tershed/mi05_160.pdf

[10] P. D. Sreedevi, K. Subrahmanyam and S. Ahmed, "The Significance of Morphometric Analysis for Obtaining Groundwater Potential Zones in a Structurally Controlled Terrain,” Environmental Geology, Vol. 47, No. 3, 2004, pp. 412-420. doi:10.1007/s00254-004-1166-1

[11] P. J. Rao, P. Harikrishna and B. S. P. Rao, "Studies on Silt Deposition in Gambhiram Reservoir-A Remote Sensing Approach,” Journal of India Geophysics Union, Vol. 10, No. 4, 2006, pp. 285-292.

[12] S. Sarkar and H. G. Gundekar, "Geomorphological Parameters: Are They Indicators for Installation of a Hydropower Site?” International Conference on Small Hydropower, Hydro Sri Lanka, 22-24 October 2007, pp. 1-7.

[13] M. Rudraiah, S. Govindaiah and S. S. Vittala, "Morphometry Using Remote Sensing and GIS Techniques in the Sub-Basins of Kagna River Basin, Gulburga District, Karnataka," Journal of Indian Society Remote Sensing, Vol. 36, No. 4, 2008, pp. 351-360. doi:10.1007/s12524-008-0035-X

[14] J. Thomas, S. Joseph and K. P. Thrivikramaji, "Morphometric Aspects of a Small Tropical Mountain River System, the Southern Western Ghats, India,” International Journal of Digital Earth, Vol. 3, No. 2, 2010, pp. 135156.

[15] P. R. Nair, "Literacy on Water, Kerala Calling,” Information and Public Relations Department, Government of Kerala, Thiruvananthapuram, 2008.

[16] P. P. N. Raj and P. A. Azeez, "Deteriorating Health Status of Kerala State, India: An Environmental and Cultural Diagnosis,” Seronica, Vol. 1, No. 1, 2010, pp. 23-27.

[17] N. Raj and P. A. Azeez, "Spatial and Temporal Variation in Surface Water Chemistry of a Tropical River, the River Bharathapuzha, India,” Current Science, Vol. 96, No. 2, 2009, pp. 245-251.

[18] CWRDM, "Master Plan for Drought Mitigation in Palakkad District,” CWRDM, Kozhikode, 2004.
[19] S. P. Ravi, C. G. Madhusoodhanan, A. Latha, S. Unnikrishnan and K. H. A. Bachan, "Tragedy of Commons: The Kerala Experience in River Linking,” River Research Centre, Trissur, 2004.

[20] P. P. N. Raj and P. A. Azeez, "Changing Rainfall in the Palakkad Plains of South India,” Atmósfera, Vol. 23, No. 1, 2010, pp. 81-88.

[21] K. Jacob and S. Narayanaswamy, "The Structural and Drainage Patteren of the Western Ghats in the Vicinity of Palghat Gap,” Proceeding of National Institute of Science India, Vol. 20, No. 1, 1954, pp. 101-118.

[22] K. S. Subramanian and M. P. Muraleedharan, "Origin of the Palghat Gap in South India-A Synthesis,” Journal of the Geological Society of India, Vol. 26, 1985, pp. 28-37.

[23] R. Vaidyanadhan, "Evolution of the Drainage of Cauvery in South India," Journal of the Geological Society of India, Vol. 12, No. 1, 1971, pp. 14-23.

[24] CESS, "Bharathapuzha and Its Problems with Special Preference to Sand Mining from the River Stretch between Chamravattom and Theirunavaya," Centre for Earth Science Studies, Thiruvanathapuram, 2004.

[25] V. T. Chow, "Handbook of Applied Hydrology," McGraw Hill, Inc., New York, 1964.

[26] S. A. Schumm, "Evolution of Drainage Systems and Slopes in Badlands at Perth Amboy, New Jersey," Geological Society of America Bullettin, Vol. 67, No. 5, 1956, pp. 597646.

doi:10.1130/0016-7606(1956)67[597:EODSAS]2.0.CO;2

[27] E. V. Giusti and W. J. Schneider, "The Distribution of Branches in River Networks,” USGS Professional Paper, Vol. 422 G, US Geological Survey, 1965.

[28] L. C. Gottschalk, "Reservior Sedimentation,” In: V. T. Chow, Ed., Hand Book of Applied Hydrology, McGraw Hill Book Company, New York, 1956, Section 7.1.

[29] K. G. Smith, "Standards for Grading Textures of Erosional Topography," American Journal of Science, Vol. 248, No. 9, 1950, pp. 655-668. doi:10.2475/ajs.248.9.655

[30] V. C. Miller, “A Quantitative Geomorphic Study of Drainage Basin Characteristics in Clinch Mountain Area, Virginia and Tennessee,” Technical Report, Columbia University, New York, 1953. 